DOI: $10.17951 / \operatorname{lrp} .2019 .38 .4 .41-58$

\author{
Beata Szabata \\ Uniwersytet Marii Curie-Skłodowskiej \\ Wydział Pedagogiki i Psychologii \\ ORCID - 0000-0002-1154-4690
}

\title{
UCZESTNICTWO OSÓB Z NIEPEŁNOSPRAWNOŚCIĄ WZROKOWĄ W KULTURZE
}

\begin{abstract}
Streszczenie: Aktywność kulturalna osób z niepełnosprawnością wzrokową pełni istotną rolę w ich rehabilitacji. Umożliwia m.in. zrozumienie siebie i poznanie własnych predyspozycji, rozwój zdolności twórczych, redukowanie przykrych napięć emocjonalnych wynikających z niepełnosprawności, tworzenie trwałych więzi z otoczeniem społecznym. Wobec tego warto bliżej przyjrzeć się formom partycypacji w kulturze osób niewidomych i słabowidzących. Ich charakterystyki dokonano na podstawie dychotomicznego podziału uwzględniającego recepcję i twórczość. Analogicznie do tych obszarów wskazano strategie „przybliżania” kultury osobom $\mathrm{z}$ niepełnosprawnością wzrokową.
\end{abstract}

Słowa kluczowe: osoby z niepełnosprawnością wzrokową, uczestnictwo w kulturze, recepcja kultury, ekspresja kultury

\section{WPROWADZENIE}

Rola społeczna osób z niepełnosprawnością wzrokową i stosunek osób pełnosprawnych do nich ulegały zmianie. Przez wiele lat utrata wzroku była traktowana w kategoriach najcięższej niepełnosprawności (Kotowski 2008, s. 20), a ludzi nią obarczonych uznawano za najbardziej poszkodowanych przez los. Sposób ich traktowania w poszczególnych kręgach kulturowych był zróżnicowany i niejednoznaczny, np. Rzymianie przyznawali niewidomym status członka rodziny, ale równocześnie funkcjonowała sprzedaż na galery i uśmiercanie, co w szczególności dotyczyło dzieci niewidomych od wczesnego dzieciństwa. Również Żydzi dawali niepełnosprawnym wzrokowo prawną ochronę, ale nie zapobiegało to jednak sprzedawaniu ich bogatym ludziom (Ingstad, Whyte; za: Żuraw 2008a, s. 163). 
Obecnie istnieją odmienne tendencje. Podejmowane są różne działania zmierzające do stworzenia osobom z niepełnosprawnością wzrokową możliwości satysfakcjonującego i wszechstronnego uczestnictwa w życiu społecznym.

Uczestnictwo społeczne jest formą aktywności podejmowaną przez grupy bądź jednostki, ukierunkowaną na ludzi lub wytwory ich działalności (Sztompka 2007, s. 450). Ten punkt widzenia zakłada, że człowiek funkcjonuje w świecie symbolicznym, w którym ciągle współistnieje z różnymi obiektami posiadającymi znaczenie. Określenie znaczenia sytuacji, w której aktualnie znajduje się jednostka jest jej podstawowym zadaniem (Żuraw 2008b, s. 16). Uczestnictwo społeczne może być badane w dwojaki sposób: całościowy lub szczegółowy (segmentacyjny). Pierwszy nurt dotyczy analiz prowadzonych w kontekście stylów życia wraz z całością ludzkiej egzystencji, ukazuje powiązania i uwarunkowania czynnikami zewnętrznymi oraz subiektywnymi zabiegami nadawania sensów. Natomiast drugi nurt obejmuje różne sfery życia społecznego (segmenty), w których zachodzą stosunki społeczne, np. czas wolny, życie rodzinne, aktywność kulturalna (Żuraw 2008b, s. 18). Według Krzysztofa Czykiera (2013, s. 63) aktywność kulturalna „wraz z takimi kategoriami, jak uczestnictwo w kulturze, uczestnictwo kulturalne, życie kulturalne, obecne są w opisach i wyjaśnianiu zjawisk związanych z partycypacją człowieka w danej kulturze [...]. Nie może istnieć uczestnictwo w kulturze bez jakiegokolwiek przejawu aktywności. W kulturze nie można uczestniczyć biernie, ponieważ każde uczestnictwo jest w jakimś stopniu aktywne”. Do tej tezy nawiązuje Ewelina Jutrzyna (2004, s. 60), która zauważa, że uczestnictwo w kulturze może przyjmować formę bezpośredniej działalności kulturalnej, w postaci czynnego uczestnictwa w celowo zorganizowanych zajęciach, spotkaniach, uprawianiu amatorskiej twórczości artystycznej w warunkach domowych, działaniach na rzecz kultury oraz formę konsumpcji wytworów kultury, z którą wiąże się także pewien rodzaj aktywności.

Niezależnie od tego, jaką formę uczestnictwa w kulturze mamy na uwadze, niezaprzeczalnym faktem są wielorakie funkcje kultury w życiu człowieka. Małgorzata Makówka (2007, s. 8-9) podkreśla, że partycypacja w kulturze zaspokaja różnorodne potrzeby człowieka (poznawcze, estetyczne, ludyczne, kontaktu społecznego, prestiżu, zagospodarowania czasu wolnego itp.), a funkcje uczestnictwa w kulturze mogą u danej osoby zmieniać się, zależnie m.in. od jej sytuacji życiowej, rodzaju treści, z którymi ma kontakt, warunków, w jakich ten kontakt zachodzi. Autorka zwraca uwagę na funkcje:

- społeczne - jest to m.in. poszerzanie wiedzy, doskonalenie sprawności umysłowych i dyspozycji twórczych człowieka; tworzenie i umacnianie więzi społecznych, stosunków międzyludzkich; kształtowanie możliwości adaptacyjnych; zwiększanie przestrzennej, zawodowej i społecznej aktywności oraz ruchliwości człowieka; 
- terapeutyczne - wyróżnia się tutaj cztery aspekty szczegółowe: dezalienacyjny - łączenie jednostki z otaczającym światem i pomaganie w eliminowaniu poczucia osamotnienia; ludyczno-rozrywkowy - odrywanie od codziennych problemów i sprzyjanie regeneracji sił odbiorcy; kompensacyjny - rekompensowanie rzeczywistych braków i stwarzanie okazji zastępczego spełniania w sferze wyobraźni; katartyczny - zapewnianie przeżyć rozładowujących napięcie i umożliwianie odzyskania stanu równowagi;

- ekonomiczne - przez funkcje ekonomiczne „rozumie się wpływ, jaki partycypacja kulturalna wywiera na aktywność gospodarczą jednostek, grup społecznych i całych społeczeństw. Jej następstwem będzie w mikroskali wzrost zamożności (lub ubóstwa) gospodarstwa domowego, natomiast w makroskali wzrost (lub regres) gospodarczy" (Makówka 2007, s. 16).

Funkcje uczestnictwa w kulturze wyodrębnił także Janusz Gajda (2008, s. 50). Są to: poszerzanie wiedzy o świecie; zwielokrotnianie doświadczeń osobistych; pomaganie w kształtowaniu i stabilizowaniu systemu wartości; ułatwianie zrozumienia drugiego człowieka i siebie; tworzenie płaszczyzny porozumienia z innymi ludźmi; umożliwianie tworzenia więzi między jednostkami i grupami.

Wprawdzie wymienione powyżej funkcje zostały opracowane z myślą o populacji ogólnej, ale zawierają przesłanki wskazujące na ich przydatność w pracy z osobami z niepełnosprawnością. W odniesieniu do tej grupy odbiorców korzystanie z dóbr kultury jest istotnym elementem podejmowanych oddziaływań rehabilitacyjnych. Warto wobec tego przedstawić propozycje funkcji uczestnictwa w kulturze osób z niepełnosprawnością, zwracające szczególną uwagę na ich specyficzne potrzeby.

Władysław Dykcik (2003, s. 14) zauważył, że partycypację w kulturze i sztuce osób z niepełnosprawnością należy analizować w kontekście takich funkcji, jak: pośredniczenie pomiędzy jednostką a społeczeństwem; organizowanie miejsc chroniących przed przemocą i agresją; przeciwdziałanie zamykaniu się w kręgu własnych problemów; organizowanie przestrzeni akceptacji, oparcia i zrównoważonego rozwoju; promowanie sukcesów i satysfakcji. Autor wyraził przekonanie, że aktywność kulturalna osób z niepełnosprawnością nie może ograniczać się do wielostronnych funkcji profilaktyczno-terapeutycznych, ale powinna być kreacją aktywnego stylu życia, organizowaniem doświadczeń kulturalnych człowieka $\mathrm{w}$ jego poznawczych i emocjonalnych relacjach $\mathrm{z}$ otaczającymśrodowiskiem.

Interesujące zestawienie funkcji uczestnictwa w kulturze w kontekście niepełnosprawności zaproponowała Hanna Żuraw (2001, s. 167-170), która wyróżniła funkcje: poznawczą (umożliwianie zrozumienia siebie i poznania własnych predyspozycji), hedonistyczną i relaksacyjną (sprzyjanie odradzaniu sił psychicznych i sprawianie przyjemności), kreatywną (stymulowanie samorealizacji i rozwoju 
zdolności twórczych), wspólnotową (ułatwianie przyswajania wzorów kulturowych przydatnych w życiu społecznym), kulturowo-synchronizującą (zbliżanie życia osób z niepełnosprawnością do egzystencji osób pełnosprawnych), egzystencjalnie-upodmiotowiającą (motywowanie do częstszego udziału w kulturze i sprzyjanie sprawowaniu kontroli nad własnym życiem), kompensacyjno-katartyczną (redukowanie przykrych napięć emocjonalnych i umożliwianie zaspokajania potrzeb psychicznych).

Uzupełnieniem zaprezentowanego obrazu są funkcje aktywności kulturalnej w odniesieniu do osób z niepełnosprawnością wzrokową sformułowane przez Ewelinę Jutrzynę (2004, s. 72-73). Autorka zwróciła uwagę na funkcje: kształcącą (rozwijanie różnych dyspozycji jednostki, np. zainteresowania, motywy aktywności kulturalnej, potrzeby estetyczne, umiejętności intelektualne, postawy społeczne); kompensacyjno-korekcyjną (rekompensowanie braków wynikających z niepełnosprawności, co przyczynia się do likwidowania odczucia niedoskonałości, przywracania wiary w sens i wartość życia); terapeutyczną (realizowanie potrzeb estetycznych, rozładowywanie różnych napięć, odwracanie uwagi od występujących dolegliwości); integracyjną (tworzenie trwałych więzi pomiędzy osobą z niepełnosprawnością a otoczeniem społecznym, poszukiwanie i nawiązywanie twórczych kontaktów z innymi osobami, posiadającymi podobne zainteresowania); profilaktyczną (zapobieganie niepożądanym zjawiskom społecznym, powstałym w efekcie niezaspokojenia potrzeb, obniżenia aspiracji życiowych i zawodowych oraz dostarczanie wzorów pożytecznego zagospodarowania czasu wolnego).

Zważywszy na funkcje związane z uczestnictwem w kulturze osób z niepełnosprawnością, w tym także z niepełnosprawnością wzrokową, i ich nieocenioną wartość rehabilitacyjną, warto blizzej przyjrzeć się formom partycypacji w kulturze osób niewidomych i słabowidzących ${ }^{1}$, które $\mathrm{z}$ racji utraty/uszkodzenia wzroku narażone są na specyficzne problemy w doświadczaniu kultury. W literaturze przedmiotu istnieje wiele klasyfikacji uczestnictwa w kulturze. Jednak w naszym kręgu kulturowym najczęściej wskazywany jest dychotomiczny podział uwzględniający recepcję i twórczość. Recepcja rozumiana jest jako „proces społecznego odbioru przekazów symbolicznych, polegających na rozumieniu treści [...] mniej więcej zgodnie z intencjami twórców, którzy je formułują" (Pichalski 1986, s. 420). Twórczość oznacza natomiast „formułowanie przekazów symbolicznych, a więc takich treści, które mają pewne znaczenie lub wartość nadaną im przez twórców" (Pichalski 1986, s. 420).

${ }^{1}$ W tekście artykułu zastosowano pisownię łączną, która nie wzbudza sprzeciwu językoznawców. Natomiast w tytułach prac źródłowych zachowano pisownię oryginalną. 


\section{UCZESTNICTWO W KULTURZE A NIEPEŁNOSPRAWNOŚĆ WZROKOWA}

Osoby z niepełnosprawnością wzrokową zainteresowane recepcją kultury mogą korzystać z oferty różnych stowarzyszeń, głównie PZN, posiadającego sieć okręgów i kół, oraz fundacji prowadzących działalność na rzecz osób niewidomych i słabowidzących. Chodzi tu głównie o działalność świetlicową, w ramach której organizowane są imprezy o charakterze kulturalnym, np. spotkania ze znanymi twórcami i wykonawcami, wystawy prac. Cenną inicjatywą są także zbiorowe wyjścia na imprezy kulturalne, np. koncerty, przeglądy zespołów, jarmarki artystyczne. Oferowana pomoc, począwszy od zdobycia informacji, poprzez zakup biletów, transport, kończąc na opiece podczas imprezy, pomaga pokonać pojawiające się w tym obszarze utrudnienia (Kotowski 2008, s. 113-115). Warto wspomnieć również o publikacjach wydawanych przez organizacje pomocowe, np. dwumiesięcznik „Pochodnia” oraz dwutygodnik „Biuletyn Informacyjny” wydawane przez PZN, w których osoby z niepełnosprawnością wzrokową mogą znaleźć informacje na temat wydarzeń kulturalnych.

Rolę podmiotów wspierających korzystanie z dóbr kultury przez osoby z niepełnosprawnością wzrokową bardzo często pełnią instytucje kulturalno-artystyczne, np. muzea, galerie, biblioteki, teatry, kina, opery, filharmonie, które współpracując z instytucjami działającymi na rzecz osób niewidomych i słabowidzących, podejmują różne inicjatywy zapewniające im dostęp do zasobów kultury. W literaturze przedmiotu wymienia się alternatywne sposoby prezentacji, m.in. europejskich obiektów muzealnych. W tym obszarze na szczególną uwagę zasługują nowatorskie rozwiązania w zakresie multisensorycznego systemu informacji oraz indywidulane i grupowe trasy do zwiedzania, które uwzględniają możliwości osób z niepełnosprawnością wzrokową, np. Galeria Dotykowa. Znaczącym udogodnieniem dla osób niewidomych i słabowidzących są także alternatywne przewodniki i plany informujące o organizacji przestrzennej obiektu, rozmieszczeniu zbiorów i eksponatów oraz zastosowanie technik elektronicznych i Internetu, tzw. muzeum wirtualne. Coraz więcej zbiorów muzealnych prezentowanych jest za pomocą audiodeskrypcji (Kłopotowska 2016, s. 307). Dobrze wykonana audiodeskrypcja jest jedynie krótkim opisem, którego interpretacji dokonuje słuchający. Twórcy zajmujący się tą problematyką uznają audiodeskrypcję za pewien rodzaj działalności artystycznej, pomagającej w doświadczaniu doznań estetycznych, a nie wyłącznie informowaniu (Wysocki 2010, s. 194). Należy również zwrócić uwagę na działania zmierzające do udostępniania osobom z niepełnosprawnością wzrokową obszarów śródmiejskich poszczególnych miast Europy i świata, zwłaszcza atrakcji turystycznych, czego efektem są specjalnie oznakowane, wyposażone w reliefy i makiety szlaki turystyczne (Kłopotowska 2016, s. 322). 
Zarysowane powyżej inicjatywy podejmowane są także w naszym kraju, gdzie niektóre muzea i galerie realizują działania ukierunkowane na dostosowanie przestrzenne i ofertowe do potrzeb osób z niepełnosprawnością wzrokową. Inspiracją do wprowadzanych zmian są nowe możliwości technologiczne. Komputeryzacja i multimedialność przekazu otwiera zakres oddziaływań na każdego odbiorcę, niezależnie od specyfiki jego funkcjonowania. Bardzo ważnym impulsem są również możliwości w zakresie współpracy i wymiany międzynarodowej pomiędzy instytucjami. Pokłosiem wymienionych działań są m.in. następujące akcje skierowane do odbiorców niewidomych i słabowidzących: wystawa rzeźb i medalionów W. Winklera w Starej Kordegardzie, alternatywne metody udostępniania zbiorów muzealnych w Muzeum Śląskim w Katowicach, projekt Zobaczyć niewidzialne realizowany przez Muzeum Narodowe w Krakowie, program Sztuka dostępna organizowany przez Narodową Galerię Sztuki Zachęta w Warszawie. Jednocześnie warto wymienić działania takich placówek muzealnych, jak: Narodowe Muzeum Morskie w Gdańsku, Muzeum Pałacu Króla Jana III w Wilanowie, Muzeum Historyczne i Muzeum Historii Fotografii w Krakowie, Muzeum Uniwersytetu Jagiellońskiego Collegium Maius. Interesującym rozwiązaniem wspierającym recepcję kultury przez osoby z niepełnosprawnością wzrokową są wirtualne muzea, np. portal Cyfrowego Muzeum Narodowego w Warszawie (Kłopotowska 2016, s. 337-344). Poza tym w Polsce, podobnie jak w innych państwach, podejmowane są próby udostępnienia osobom niewidomym i słabowidzącym obszarów miejskich, zwłaszcza zabytków. Wykorzystuje się przede wszystkim modele i makiety zabytków oraz przewodniki z audiodeskrypcją.

Intensywne działania ukierunkowane na umożliwienie osobom z niepełnosprawnością wzrokową recepcję kultury objęły swoim działaniem także biblioteki. Podejmowane inicjatywy realizowane są głównie dzięki udostępnianiu zbiorów w alternatywnej formie. Oprócz pozycji drukowanych pismem punktowym i powiększoną czcionką, których niestety nie ma zbyt wiele, dostępne są książki mówione i książki cyfrowe. Biblioteki dla osób niewidomych i słabowidzących oraz niektóre publiczne oferują swoim czytelnikom elektroniczne książki i czasopisma, z systemem nawigacji, tworzone w różnych formatach: HTML, ASCIL, PDF, DOC, oraz cyfrowe książki mówione w formacie MP3 i DAISY (Ślusarczyk 2008, s. 68). System nawigacji w znaczącym zakresie ułatwia poruszanie się po tekście i pracę z tekstem, np. wyszukiwanie rozdziałów, robienie zakładek, sporządzanie notatek lub cytatów. Poza tym osoby słabowidzące mogą dostosować obraz do swoich potrzeb, np. dowolnie powiększyć tekst, zmienić krój czcionki, ustawić kontrast czcionki z tłem. Dzięki wersji audio możliwa jest regulacja prędkości czytania, wysokości głosu oraz skonfigurowanie innych funkcji. E-książki są cenione przez czytelników i bibliotekarzy. Jedną z pierwszych bibliotek publicznych, zmodernizowanych z myślą o czytelnikach 
z niepełnosprawnością wzrokową, była Biblioteka Uniwersytecka w Warszawie (Kłopotowska 2016, s. 346-347).

Osoby niewidome i słabowidzące mają możliwość korzystania $\mathrm{z}$ takich form kulturalnych, jak sztuka teatralna i sztuka filmowa. Kulturę obrazu można doskonale przedstawić niepełnosprawnym wzrokowo, wykorzystując w tym celu audiodeskrypcję. Ma ona pokazać to, co jest w przekazie najcenniejsze i najbardziej wartościowe. W literaturze podkreśla się, że audiodeskrypcja teatralna nie różni się zbytnio od audiodeskrypcji filmowej. Oba rodzaje opisują sztukę audiowizualną i są ograniczone czasem, ponieważ tekst czytany przez lektora musi zmieścić się pomiędzy dialogami. Różnice dotyczą specyfiki przedstawienia teatralnego, które jest wydarzeniem jednorazowym, dziejącym się na żywo i zawsze zawierającym element niespodzianki (Szarkowska, Künstler 2014, s. 94-95). W ostatnich latach podjęto wiele inicjatyw zmierzających do udostępnienia zasobów sztuki teatralnej i filmowej osobom z niepełnosprawnością wzrokową. Na szczególną uwagę zasługuje działalność Fundacji Dzieciom „Zdążyć z Pomocą”, która w ramach projektu Poza Cisza i Ciemnością przygotowała 28 spektakli z audiodeskrypcją, opracowała audiodeskrypcję do 24 produkcji kinowych, 5 filmów ogólnodostępnych oraz przygotowała ścieżkę audiodeskrypcyjną do występu Ludowego Zespołu Pieśni i Tańca „Mazowsze”. Warto również wspomnieć o działalności Fundacji Audiodeskrypcja, która przeprowadziła szereg akcji z zakresu udostępniania dzieł filmowych i teatralnych osobom niewidomym i słabowidzącym oraz zapoczątkowała podobne inicjatywy w całym kraju, np. program realizowany przez PZN mający na celu wymianę doświadczeń $\mathrm{w}$ zakresie udostępniania warszawskich teatrów. Wśród placówek, które podjęły tego typu działania, znalazły się m.in. Królewski Teatr Pałacu w Wilanowie i Teatr Narodowy. Fundacja Audiodeskrypcja wyakcentowała także konieczność szkolenia podmiotów zajmujących się dystrybucją sztuki, czego pokłosiem stał się program „Kultura przeciw Wykluczeniu - Audiodeskrypcja”, zmierzający do przekazania wiedzy i umiejętności z zakresu audiodeskrypcji osobom odpowiedzialnym za ofertę życia kulturalnego w Warszawie (Kłopotowska 2016, s. 347-349). Jest to bardzo ważne przedsięwzięcie, gdyż, jak pokazują dotychczasowe badania, przeprowadzone wśród osób z niepełnosprawnością wzrokową korzystających z wydarzeń audiodeskrybowanych realizowanych przez Fundację Kultury Bez Barier, respondenci nisko ocenili zarówno ich dostępność, jak i częstotliwość korzystania z nich. 80\% badanych uważa, że wydarzeń audideskrybowanych jest mało lub bardzo mało. Ponad połowa osób niewidomych i słabowidzących uczestniczyła w nie więcej niż 10 takich wydarzeniach. $48 \%$ badanych korzystało z audiodeskrypcji podczas seansów filmowych, a 26\% podczas przedstawień teatralnych (Pietruszyńska 2015; za: Paplińska 2016, s. 184). 
Dobrem kultury najbardziej dostępnym osobom z niepełnosprawnością wzrokową, którego recepcja nie wymaga żadnych wyjaśnień, komentarzy czy też przewodników, jest muzyka, docierająca do odbiorcy poprzez słuch, zmysł niezaburzony defektem wzroku. Powiązanie sfery słuchowej z emocjonalnością przyczynia się do tego, że muzyka jest w pełni przyjmowana i przyswajana przez osoby niewidome i słabowidzące, bez zaangażowania zarówno uszkodzonego wzroku, jak i takich analizatorów zastępczych, jak dotyk, węch czy smak. Jest dziedziną sztuki szczególnie silnie i bezpośrednio oddziałującą na całą osobowość człowieka (Cylulko 2008, s. 67), a zarazem skutecznym narzędziem umożliwiającym nawiązywanie kontaktów interpersonalnych (Ham, Kim 2004, s. 100). Nie jest zatem zbytnim zaskoczeniem, iż osoby z niepełnosprawnością wzrokową, w porównaniu z osobami pełnosprawnymi wzrokowo, ujawniają znacznie bardziej pozytywne postawy wobec muzyki (Park, Chong, Kim 2015, s. 311), czego wyrazem są częste wyjścia do opery czy też filharmonii. Interesujące, że niewidomi w większym zakresie niż słabowidzący cenią sobie możliwość korzystania z oferty tych instytucji kulturalnych (Wysocki 2010, s. 68).

Osoby z niepełnosprawnością wzrokową mogą być nie tylko odbiorcami kultury, ale są także w stanie ją tworzyć. Wielu osobom niewidomym i słabowidzącym bardzo bliska jest twórczość muzyczna, zarówno śpiew, jak i gra na instrumentach muzycznych. Trzeba jednak pamiętać, że nie jest prawdą, by wszyscy niepełnosprawni wzrokowo posiadali wrodzone zdolności muzyczne. Wprawdzie wrażenia słuchowe są istotnym mechanizmem kompensacyjnym, ale osiągnięcia muzyczne, szczególnie sukcesy, są efektem ciężkiej pracy, wytrwałości oraz zależą od kompetencji osób zajmujących się kształceniem muzycznym (Konarska 2006, s. 249). Znaczące osiągnięcia w tym obszarze odnieśli Zdzisław Skwara i Henryk Wereda. Pierwszy z nich był wychowawcą wielu niewidomych śpiewaków, a drugi muzyków instrumentalistów. Jeśli chodzi o kształcenie głosu, to bardzo często jest stosowana metoda polegająca na wykorzystaniu percepcji dotykowej, zarówno podczas obserwowania pracy aparatu oddechowego i sylwetki osoby śpiewającej, jak i podczas korygowania układu ust i nieprawidłowości w postawie. Metoda ta jest skuteczna na każdym etapie edukacji muzycznej, również w zawodowym kształceniu muzycznym, gdzie prawidłowo funkcjonujący aparat głosowy jest konieczny dla uzyskania statusu zawodowego śpiewaka (Nazarko 2001, s. 289). Wśród wybitnych niewidomych śpiewaków polskiego pochodzenia znajdują się m.in. Ewa Błoch, Bronisław Harasiuk, Jolanta Kaufman, Janusz Kowalski, Alicja Pałczyńska. Światową sławę osiągnęli Andrea Bocelli, Ray Charles, Stevie Wonder. Nauka gry na instrumentach muzycznych, podobnie jak kształcenie głosu, odbywa się przy znaczącym udziale zasady poglądowości. Natomiast podczas nauki gry konkretnych utworów stosowane są dwie metody: słuchowo-pamięciowa oraz z wykorzystaniem nut brajlowskich 
(Nazarko 2001, s. 296). Instrumentem, na którym nauka gry sprawia osobom niewidomym wyjątkowe trudności, jest pianino. Wprawdzie wyraźne oddzielenie klawiszy jest dużym ułatwieniem, ale sprawy techniczne, np. swobodne poruszanie się po klawiaturze, bezbłędne trafianie w odpowiednie klawisze, sprawiają duże trudności, szczególnie początkującym pianistom. Opanowanie gry na pianinie przez osobę niewidomą nie jest jednak umiejętnością niemożliwą. Dowodem na to są osiągnięcia Edwina Kowalika, laureata jednego z konkursów chopinowskich (Konarska 2006, s. 249-250), oraz Janusza Skowrona, pianisty jazzowego. Inni równie znani zawodowi niewidomi muzycy instrumentaliści to Tadeusz Golachowski (saksofonista jazzowy) i Marek Mielnik (organista) (Nazarko 2001, s. 286).

Znacząca grupa osób z niepełnosprawnością wzrokową zajmuje się twórczością literacką, gdzie ważne miejsce zajmuje literatura wspomnieniowa, ale również takie gatunki, jak: poezja, fraszki, humoreski, aforyzmy, reportaże, opowiadania (Kuczyńska-Kwapisz 2009, s. 96). Interesującą eksplorację dorobku piśmienniczego autorów niewidomych i słabowidzących, pochodzącego z lat 1945-2008, przeprowadziła Małgorzata Czerwińska (2013, s. 81). Autorka objęła badaniami 493 osoby z niepełnosprawnością wzrokową, sporadycznie lub systematycznie zajmujące się twórczością literacką. Okazało się, że wśród publikacji drukowanych najliczniej reprezentowana jest literatura piękna, a zwłaszcza tomy poetyckie. W tym obszarze najwięcej prac przygotowali Maksymilian Bart-Kozłowski i Stanisław L. Machowiak. W kategorii powieści znamienny jest dorobek Hanny Muszyńskiej-Hoffmannowej oraz Jerzego Szczygła. Natomiast najwięcej opowiadań napisali Bronisław Mróz-Długoszewski i Zbigniew Przyrowski. W kategorii literatury faktu dominują wspomnienia, gdzie wymieniani są m.in. Janusz W. Szymański, Roman Bańkowski, Tytus Karpowicz. Piśmienniczość twórców niewidomych i słabowidzących obejmuje także literaturę popularnonaukową, literaturę dydaktyczną, wydawnictwa informacyjne oraz literaturę naukową. Autorzy z niepełnosprawnością wzrokową są laureatami licznych konkursów, np. konkurs „Zielonego Sztandaru” im. Macieja Rataja, Ogólnopolskie Konkursy im. Mikołaja Reja i Stefana Żeromskiego oraz prestiżowych nagród literackich, np. Nagroda Literacka im. ks. Jana Twardowskiego, nagroda ZAIKS-u im. Karola Małcużyńskiego, Nagroda im. Jarosława Iwaszkiewicza w dziedzinie upowszechniania kultury. Otrzymali też wiele odznaczeń państwowych i resortowych, np. Krzyż Komandorski Orderu Odrodzenia Polski, Krzyż Kawalerski Orderu Odrodzenia Polski, Złota Odznaka Janka Krasickiego. Poza tym autorzy niewidomi i słabowidzący legitymują się członkostwem stowarzyszeń twórczych, klubów i grup literackich, w których pełnią niekiedy ważne funkcje. Są związani z organizacjami samopomocowymi, najczęściej jest to PZN, gdzie podejmują liczne inicjatywy na rzecz środowiska osób z niepełnosprawnością wzrokową. Wielu z nich, ze względu na swoją biografię, postawę życiową, osiągnięcia 
twórcze, aktywność życiową i społeczną, zapisało się w świadomości społecznej i funkcjonuje w przekazach medialnych. Niestety niewielu za swój życiowy sukces uznaje działalność literacką (Czerwińska 2013, s. 88-94).

Wśród osób z niepełnosprawnością wzrokową są również wysoko cenieni tancerze. Dzięki odpowiednim metodom nauczania taniec może stać dla nich prawdziwą pasją. Aby osoba z niepełnosprawnością wzrokową, zwłaszcza niewidoma, podjęła taką próbę, musi zostać odpowiednio do tego przygotowana, czemu służą specjalne zajęcia. Ich podstawą jest dobra świadomość własnego ciała oraz odpowiednie przygotowanie fizyczne, zmierzające do wypracowania u przyszłego tancerza wielu pożądanych cech, np. właściwa postawa ciała, płynność i elegancja ruchu, rytmiczność. Pracując z osobami z niepełnosprawnością wzrokową, trzeba pamiętać o optymalnych warunkach prezentacji wzorców ruchowych, co w odniesieniu do tancerzy słabowidzących oznacza m.in. zachowanie odpowiedniej odległość od obserwatora, korzystne oświetlenie sali i osób tańczących, a w przypadku tancerzy niewidomych - dotykowy ogląd sekwencji ruchowych figur, wykonywanych w zwolnionym tempie. Wachlarz technik tanecznych, w jakich mogą realizować się osoby z niepełnosprawnością wzrokową, jest szeroki (balet, taniec towarzyski, ludowy, dyskotekowy). Problematyczny wydaje się taniec tzw. integracyjny, szczególnie gdy partnerzy są niewidomi (Kłopotowska 2016, s. 400). W takiej sytuacji niezwykle przydatna jest metoda opracowana przez Wacława Wróblewskigo (2005, s. 40), której podstawą jest sześciopunkt Braille’a. Istotną kwestią dla tancerzy z niepełnosprawnością wzrokową jest poczucie bezpieczeństwa na scenie. Może być ono wzmacniane przy użyciu różnorodnych środków, np. rozmieszczanie sznurów na podłodze, oznaczanie punktów orientacyjnych na scenie, oraz zdobyczy współczesnej techniki. Doskonałym przykładem jest przyrząd podobny do aparatu słuchowego, pozwalający na swobodne poruszanie się po scenie. Urządzenie informuje o podejściu do niewidocznych laserów, którymi zaznaczone są granice sceny. $Z$ wymienionych rozwiązań z powodzeniem korzystają wybitne tancerki niewidome, m.in. Mana Hashimoto i Nola Baker-Jones. W wielu krajach istnieją szkoły zajmujące się kształceniem niewidomych tancerzy, w których wdrażane są różne rozwiązania praktyczne. Fernanda Bianchini, założycielka Association of Ballet of Blind People, opracowała technikę, która pozwala niepełnosprawnym wzrokowo tancerzom utrzymywać prostą postawę i równowagę oraz metodę orientowania się w przestrzeni. Pomysły te są weryfikowane w szkole baletowej dla niewidomych uczniów w São Paulo. Warto także wspomnieć, że w Bangalore (Indie) w Shree Ramana Maharishi Academy for the Blind założono zawodową grupę tańca, której członkowie z niepełnosprawnością wzrokową polegają wyłącznie na słuchu oraz wykrywaniu pozycji partnerów na scenie. Wielu absolwentów wymienionych placówek zostaje zawodowymi tancerzami, a ekspresja sztuki jest dla nich źródłem utrzymania (Jałocha 2006, s. 37-139). 
Niektóre osoby z niepełnosprawnością wzrokową realizują się w twórczości plastycznej, przy czym rodzaj podejmowanej w tym obszarze aktywności zależy od stopnia i czasu utraty/uszkodzenia wzroku. Osoby niewidome często zajmują się rzeźbiarstwem, odwołującym się do wyobraźni przestrzenno-dotykowej, np. twórczość Antoniego Dobrowolskiego, odzwierciedlającego w drewnie przedmioty i baśniowe postacie. Jego prace są realistyczne i zabawne (Konarska 2006, s. 249). Innym popularnym niewidomym rzeźbiarzem jest Jan Makowiecki², mający w swoim dorobku prace o tematyce sakralnej i świeckiej, płaskorzeźby, dzieła przestrzenne, za które niejednokrotnie otrzymywał nagrody i wyróżnienia. Bardzo rzadko spotyka się niewidomych malarzy, chociaż i tutaj zdarzają się pewne wyjątki. Jest nim z pewnością postać malarza tureckiego Eşrefa Armağana. Ten niewidomy od urodzenia artysta, wykorzystując wrodzoną umiejętność bezwzrokowego wyczuwania barw na podstawie wrażeń dotykowych, tworzy pełnowartościowe obrazy (pejzaże, portrety), które zadziwiają odbiorców nie tylko dojrzałą kompozycją, ale także zastosowaniem światłocienia, perspektywy oraz wrażliwym mieszaniem barw (Kłopotowska 2016, s. 409). Pomijając jednak kwestię synestezji, która wzbudza wiele wątpliwości, większe oczekiwania wiązane są z zastosowaniem w malarstwie farb zapachowych czy też taktylnych. Interesującą inicjatywą jest stworzenie jednolitego dla poszczególnych krajów kodu fakturalnego, odpowiadającego poszczególnym barwom. Rozwiązanie to wzbudza wielkie nadzieje, gdyż jest zapowiedzią opracowania metody umożliwiającej korzystanie z kolorów w warunkach bezwzrokowych (Kłopotowska 2016, s. 427-428). Z kolei osoby słabowidzące najbardziej skłaniają się ku malarstwie. Znanym twórcą jest Tomasz Kalinowski ${ }^{3}$ który maluje i rysuje (akryl, tempera) głównie pejzaże. Artysta bierze udział w wielu plenerach. Warto również wspomnieć o słabowidzącej malarce Elżbiecie Łysoniewskiej ${ }^{4}$, której prace olejne można zobaczyć na licznych wystawach zbiorowych i indywidualnych w całej Polsce.

Uczestnictwo w kulturze osób z niepełnosprawnością wzrokową stało się przedmiotem prac empirycznych. Zwróciła na nie uwagę m.in. Hanna Żuraw (2008b, s. 169-181), która przeprowadziła badania wśród 330 osób z niepełnosprawnością w wieku 35-40 lat, w tym 90 niewidomych. Podstawową techniką badań był wywiad w formie rozmowy naprowadzanej. Uzyskany materiał empiryczny pozwolił wyodrębnić cztery typy uczestnictwa w życiu kulturalnym: uczestnictwo recepcyjne

2 Wystawa rzeźby Jana Makowieckiego, opublikowano: https://pzn.org.pl/wystawa-rzezby-jana-makowieckiego [dostęp: 21.08.2019].

${ }^{3}$ Wystawa Tomasza Kalinowskiego, opublikowano: https://pzn.org.pl/wystawa-tomasza-kalinowskiego [dostęp: 21.08.2019].

${ }^{4}$ Wystawa malarstwa Elżbiety Łysoniewskiej - „Mój świat barw”, opublikowano: https://pzn. org.pl/wernisaz-elzbiety-lysoniewskiej-w-tyflogalerii [dostęp: 21.08.2019]. 
ograniczone do środków masowego przekazu, uczestnictwo recepcyjne poszerzone o czytelnictwo, uczestnictwo recepcyjne poszerzone o czytelnictwo i wizyty w instytucjach kulturalnych, uczestnictwo ekspresyjno-recepcyjne. Wśród badanych najbardziej popularne było uczestnictwo recepcyjne ograniczone do korzystania ze środków masowego przekazu. Znacznie rzadziej wskazywano warianty uczestnictwa rozszerzonego, przy bardzo zbliżonych preferencjach w obu przypadkach uczestnictwa, a najrzadziej pojawiało się uczestnictwo ekspresyjno-recepcyjne. $\mathrm{Na}$ tej podstawie można wnioskować, że korzystanie z dóbr kultury było wśród badanych powszechną formą uczestnictwa społecznego. Dominowały zajęcia recepcyjne, a zwłaszcza korzystanie z przekazu audiowizualnego w warunkach domowych, które dostarczały rozrywki i stwarzały pozory autentycznego udziału w wydarzeniach. Mniejsze rozpowszechnienie pozostałych typów uczestnictwa można tłumaczyć koniecznością większego zaangażowania sił i środków, zwłaszcza w przypadku uczestnictwa ekspresyjno-recepcyjnego. Interesujące, że uczestnictwo recepcyjne poszerzone o czytelnictwo i wizyty w instytucjach kulturalnych oraz uczestnictwo ekspresyjno-recepcyjne najliczniej występowały wśród osób niewidomych. Tendencje te jednoznacznie wskazują, że brak wzroku jest czynnikiem sprzyjającym intensyfikacji partycypacji w kulturze.

Na uwagę zasługują także badania Anny Nowak (2015, s. 94-96), która podjęła próbę empirycznego określenia udziału kobiet z niepełnosprawnością w życiu kulturalnym oraz ich dostępu do instytucji kultury. Autorka objęła badaniami 50 kobiet, wśród których znalazły się respondentki z niepełnosprawnością wzrokową. Materiał badawczy zebrała za pomocą wywiadu. Eksploracja ujawniła, że korzystanie $\mathrm{z}$ dóbr kultury jest dla badanych istotną formą aktywności życiowej, często podejmowaną. $1 / 5$ respondentek zdeklarowała systematyczne uczestnictwo $\mathrm{w}$ różnych imprezach kulturalnych. Kobiety z niepełnosprawnością preferowały korzystanie z przekazu audiowizualnego, głównie filmy i muzykę dostępne za pomocą telewizji, oraz grupowe wyjścia do kina, dające im okazję spotkania ze znajomymi. W centrum zainteresowania badanych znajdowały się lokalne propozycje kulturalne o różnym charakterze. Niektóre kobiety z niepełnosprawnością dały się także poznać jako twórcy kultury. Realizowały się głównie w zakresie działalności literackiej i muzycznej. Respondentki zwróciły uwagę na rolę stowarzyszeń i instytucji w zakresie udostępniania kultury osobom z niepełnosprawnością, np. Polski Związek Niewidomych, Fundacja Pomocy Osobom Niepełnosprawnym. Poza tym stwierdziły, że wiele instytucji kultury jest nieprzystosowanych do potrzeb osób z niepełnosprawnością, a pracownicy kultury wykluczają je z życia kulturalnego, do czego przyczynia się ograniczanie dostępu do usług i nieanimowanie działań ze względu na funkcjonujące stereotypy. Z badań wynika, że można wyróżnić cztery grupy czynników powodujących wykluczanie kobiet z niepełnosprawnością z życia 
kulturalnego: właściwości kobiet (brak atrakcyjności, zależność od innych, cechy osobowości, samowykluczanie się z tego obszaru życia); bariery społeczno-kulturalne (negatywne postawy, uprzedzenia, brak akceptacji, brak doświadczeń wyniesionych z domu rodzinnego); bariery ekonomiczne (brak środków finansowych, brak wydarzeń kulturalnych w miejscu zamieszkania); bariery architektoniczne (niedostosowanie środków komunikacji miejskiej, peronów i dworców do potrzeb osób z niepełnosprawnością). Zważywszy na to, że partycypacja w kulturze jest istotnym elementem aktywizacji kobiet $\mathrm{z}$ niepełnosprawnością, umożliwiającym włączenie w życie społeczne, wykluczanie ich z tego obszaru jest działaniem niepokojącym i o dużym stopniu szkodliwości społecznej.

W analizie problematyki uczestnictwa w kulturze osób niewidomych i słabowidzących warto zwrócić uwagę na jego uwarunkowania wyróżnione przez Ewelinę Jutrzynę (2004, s. 60-71), tj. uwarunkowania społeczne i osobowościowe. Do pierwszej grupy autorka zaliczyła: bariery architektoniczne, relacje międzyludzkie, stopień dostępności instytucji upowszechniania kultury i dóbr kultury, problem otwartości niepełnosprawnych wzrokowo na kontakty interpersonalne, poziom wiedzy osób pełnosprawnych na temat problemów osób niewidomych i słabowidzących. Natomiast w drugiej umieściła: wiek, płeć, stan cywilny, wykształcenie, temperament, poziom inteligencji emocjonalnej, zdolności, aspiracje, potrzeby, rodzaj i stopień niepełnosprawności. Wymienione uwarunkowania nie stanowią rozłącznych grup, są one ściśle ze sobą powiązane.

Z zaprezentowanego materiału wynika zatem, że kwestia partycypacji w kulturze osób z niepełnosprawnością wzrokową jest bardzo złożona. Należy ją rozważać na kilku płaszczyznach, gdyż tylko takie podejście jest słuszne, by przedstawić recepcję i ekspresję kultury będącą udziałem osób niewidomych i słabowidzących.

\section{PODSUMOWANIE}

Analiza problematyki dotyczącej uczestnictwa w kulturze osób z niepełnosprawnością wzrokową pozwala stwierdzić, że sytuacja tej grupy osób ulega poprawie, szczególnie pod względem recepcji dóbr kultury. Wzrasta bowiem liczba projektów zmierzających do udostępniania dóbr kultury osobom niewidomym i słabowidzącym, np. dzięki inicjatywom związanym z zastosowaniem audiodeskrypcji niepełnosprawni wzrokowo mają możliwość uczestniczenia w różnych wydarzeniach kulturalnych (m.in. seanse teatralne, filmowe, wystawy muzealne) oraz prowadzenia dyskusji na ten temat na równi z osobami pełnosprawnymi, nie ograniczając się w tym zakresie do środowiska osób z niepełnosprawnością, co zapobiega ich wykluczeniu ze społeczeństwa (Paplińska 2016, s. 191). Podejmowane 
działania przyjmują różną postać: od systemowo realizowanych programów po spontaniczne inicjatywy. Doceniając dotychczas zrealizowane działania, trudno nie zauważyć, że bardzo często mają one charakter pojedynczych akcji, których efekt jest chwilowy. Wdrażane dzięki nim rozwiązania funkcjonują w ramach konkretnego projektu i znikają z chwilą jego zakończenia. W tej sytuacji niezbędne staje się opracowanie kompleksowej strategii „przybliżania” kultury osobom z niepełnosprawnością wzrokową, łączącej inicjatywy różnych podmiotów, których działania są ukierunkowane na tworzenie przyjaznego środowiska kultury. Powinny one być prowadzone równoległe w trzech obszarach: realizacja fizycznej i informacyjnej dostępności instytucji kultury i sztuki (przyjazny obiekt w przyjaznym otoczeniu), realizacja misji tyflodydaktycznej (udostępnienie dóbr kultury osobom niewidomym i słabowidzącym), dbałość o społeczną akceptację działań nakierowanych na otwieranie kultury i sztuki na odbiorców z niepełnosprawnością wzrokową (społeczne przyzwolenie sprzyjające rzeczywistej integracji) (Kłopotowska 2016, s. 355-356).

Biorąc pod uwagę twórczość osób z niepełnosprawnością wzrokową, istotnymi elementami strategii umożliwiającymi ekspresję kultury muszą stać się przemyślane działania edukacyjne, przygotowujące absolwentów niewidomych i słabowidzących do samodzielnego tworzenia kultury i sztuki. Zorganizowane kształcenie nie jest jednak wystarczającym przedsięwzięciem. Nieocenione znaczenie mają także działanie wspomagające artystów z niepełnosprawnością wzrokową (Kłopotowska 2016, s. 436), w czym bardzo pomocne są różne fundacje i stowarzyszenia. Organizowanie plenerów, warsztatów pracy twórczej, drukowanie wierszy, opowiadań, przyznawanie stypendiów, zapraszanie do udziału w różnych imprezach, np. wystawy, przeglądy twórczości, może wzmocnić potencjał twórców z niepełnosprawnością wzrokową oraz zachęcić ich następców do podejmowania wyzwań artystycznych. Wiele cennych inicjatyw pojawiło się dzięki działalności Krajowego Centrum Kultury Niewidomych w Kielcach (Szostak 2008, s. 132-135), Klubu Twórczości „ŻAR” w Warszawie (Stopierzyńska-Siek 2008, s. 146-152) oraz Towarzystwa Muzycznego im. Edwina Kowalika w Warszawie (Milewska 2008, s. 179-186).

W analizie problemu twórczości osób z niepełnosprawnością wzrokową nie można pominąć ważnego aspektu, jakim jest oddziaływanie jej na całe środowisko osób niewidomych i słabowidzących, które dzięki sukcesom innych mają możliwość zrozumienia, że człowiek nigdy nie znajduje się na straconej pozycji, że z utratą/uszkodzeniem wzroku nie muszą wiązać się wyłącznie wartości negatywne. Przeciwnie, sytuacja taka może być punktem zwrotnym, stwarzającym okazję do pojawienia się nowych, twórczych zachowań (Czerwińska 2008, s. 62). Kwestią niejasną pozostaje jednak sposób oceniania twórczości osób z niepełno- 
sprawnością wzrokową. Twórczość ta jest przede wszystkim sposobem autorehabilitacji i szansą na samorealizację. „I w tym właśnie, a nie w efektach widocznych na polu artystycznym, należy upatrywać największą wartość uprawiania sztuki przez osoby z niepełnosprawnością" (Czerwińska 2003, za: Czerwińska 2008, s. 55-56).

Możliwości rozwojowo-edukacyjne osób z niepełnosprawnością kształtowane przez aktywność kulturalną są niezbadane i niedoceniane, niekiedy znacznie większe niż zakładają to potoczne opinie. $\mathrm{W}$ coraz większym zakresie mamy do czynienia z terapią przez sztukę oraz realizacją zadań rehabilitacji społecznej poprzez aktywność kulturalną osób z niepełnosprawnością, szczególnie w zakresie kształtowania postaw życiowych i ludzkich zachowań traktowanych w kategoriach mechanizmów, które wyzwalają psychiczną i społeczną autonomię. Wychodzenie naprzeciw potrzebom kulturalnym osób z niepełnosprawnością ściśle odnosi się do idei wyrażających się w dążeniu do partnerstwa, integracji, aktywnej partycypacji w życiu społecznym. W kontekście edukacji kulturalnej realne staje się wychowanie $\mathrm{w}$ duchu radości życia, co jest możliwe dzięki równoczesnemu stawianiu wymagań, ujawnianiu napełnionych optymizmem oczekiwań i doświadczeń służących podejmowaniu twórczych rozwiązań. Szczególnego znaczenia nabiera więc kształtowanie realistycznej postawy, której podstawą jest pozytywne nastawienie serca i umysłu, zmierzającej do rozumienia aktualnej rzeczywistości zgodnie z własnym psychicznym odbiorem świata i ludzi, a zwłaszcza zmierzającej do kreowania przyszłości zgodnie z wizją własnego życia (Dykcik 2003, s. 12-13).

\section{LITERATURA}

Cylulko P., 2008, Wybrane refleksje nad tyflomuzykoterapia. ,Przegląd Tyflologiczny”, $1-2,67-79$.

Czerwińska M., 2013, „Jesteście więksi ode mnie tylko o światło” - o autorach $z$ niepelnosprawnościq wzroku - między rehabilitacja a życiem literackim. W: T. Żółkowska, M. Wlazło (red.), Edukacja i rehabilitacja osób niepełnosprawnych - oblicza terapii. Szczecin, Wydawnictwo USz, 79-97.

Czykier K., 2013, Audiowizualne doświadczanie świata. Kontekst międzypokoleniowy. Warszawa, Wydawnictwo Akademickie „Żak”.

Dykcik W., 2003, Aktywność w kulturze i sztuce podstawa edukacji i twórczego życia osób niepetnosprawnych. W: E. Jutrzyna (red.), Sztuka w życiu i edukacji osób niepetnosprawnych. Wybrane zagadnienia. Warszawa, Wydawnictwo APS, 9-18. Gajda J., 2008, Antropologia kulturowa. Wprowadzenie do wiedzy o kulturze. Cz. 1. Kraków, Wydawnictwo „Impuls”. 
Ham D., Kim Y., 2004, A study on the recreation and leisure activities of the visually impaired students. „The Korean Journal of Visual Impairment \& Blindness”, 20(1), 91-117.

Jałocha M., 2006, Niepetnosprawny tancerz. W: J. Baran, S. Olszewski (red.), Świat pełen znaczeń - kultura i niepełnosprawność. Kraków, Wydawnictwo „Impuls”, 133-146.

Jutrzyna E., 2004, Uczestnictwo w kulturze osób niewidomych. W: Z. Konaszkiewicz (red.), Muzyka w życiu osób niepełnosprawnych. Warszawa, Wydawnictwo AM, 59-73. Kłopotowska A., 2016, Doświadczanie przestrzeni $w$ rehabilitacji osób z dysfunkcja wzroku. Sztuka a tyflorehabilitacja. Białystok, Wydawnictwo PB.

Konarska J., 2006, Rehabilitacyjny aspekt udziału osób niepełnosprawnych $w$ tworzeniu dóbr kultury. W: J. Baran, S. Olszewski (red.), Świat pełen znaczeń - kultura i niepełnosprawność. Kraków, Wydawnictwo „Impuls”, 241-251.

Kotowski S., 2008, Przewodnik po problematyce osób niewidomych i słabowidzących. Warszawa, Wydawnictwo Fundacja Polskich Niewidomych i Słabowidzących „Trakt”.

Kuczyńska-Kwapisz J., 2009, Pedagogika osób słabo widzących i niewidomych. W: D.M. Piekut-Brodzka, J. Kuczyńska-Kwapisz (red.), Pedagogika specjalna dla pracowników socjalnych. Warszawa, Wydawnictwo APS, 88-102.

Makówka M., 2007, Funkcje uczestnictwa w kulturze. „Zeszyty Naukowe Akademii Ekonomicznej w Krakowie”, 742, 5-22.

Milewska H., 2008, Towarzystwo Muzyczne im. Edwina Kowalika. „Przegląd Tyflologiczny", 1-2, 178-187.

Nazarko G., 2001, Dziedziny artystyczne. W: S. Jakubowski (red.), Poradnik dydaktyczny dla nauczycieli realizujących podstawe programowa $w$ zakresie szkoły podstawowej i gimnazjum z uczniami niewidomymi i słabo widzacymi. Warszawa, Wydawnictwo MEN, 284-300.

Nowak A., 2015, Uczestnictwo osób niepełnosprawnych w kulturze. „Chowanna”, 1, 91-102.

Paplińska M., 2016, Niewidomy odbiorca sztuki - społeczne, edukacyjno-rehabilitacyjne znaczenie audiodeskrypcji przedstawień teatralnych dla osób z niepełnosprawnościa wzroku. „Forum Pedagogiczne”, 1, 181-194. DOI: 10.21697/fp.2016.1.12.

Park H.Y., Chong H.J., Kim S.J., 2015, A comparative study on the attitudes and uses of music by adults with visual impairment and those who are sighted. „Journal of Visual Impairment \& Blindness", 100(9), 303-316.

Pichalski R., 1986, Nieprofesjonalna twórczość ludzi niepełnosprawnych i petnosprawnych. W: A. Hulek (red.), Człowiek niepełnosprawny w społeczeństwie. Warszawa, Wydawnictwo PZWL, 419-422.

Stopierzyńska-Siek I., 2008, Klub Twórczości „ŻAR” - ramy artystycznego dojrzewania. „Przegląd Tyflologiczny”, 1-2, 142-159. 
Szarkowska A., Künstler I., 2014, Audiodeskrypcja w kinie, teatrze, muzeum. Wprowadzenie do działań praktycznych. W: M. Trzeciakiewicz (red.), Audiodeskrypcja $w$ teorii i praktyce, czyli jak mówić o tym, czego nie można zobaczyć, 65-106, opublikowano: http://www.culturamentis.org/aktualnosci/pwp-do-przodu-podrecznikido-pracy-z-osobami-niewidomymi/ [dostęp: 12.08.2019].

Szostak A., 2008, Krajowe Centrum Kultury Polskiego Związku Niewidomych - terapia i sztuka. W kręgu osobistych doświadczeń. „Przegląd Tyflologiczny”, 1-2, 126-141.

Sztompka P., 2007, Zmiana społeczna, rozwój, postęp. W: Sztompka P. (red.), Socjologia: analiza społeczeństwa. Kraków, Wydawnictwo „Znak”, 437-453.

Ślusarczyk C., 2008, Dostęp osób z niepełnosprawnościa wzroku do słowa pisanego a technologie informacyjne. W: M. Czerwińska, T. Dederko (red.), Niewidomi w świecie książek i bibliotek. Wybrane zagadnienia. Kielce, Wydawnictwo STON, 64-72.

Wróblewski W., 2005, Taniec towarzyski w rehabilitacji niewidomych. Poznań, Wydawnictwo AWF.

Wysocki M., 2010, Projektowanie otoczenia dla osób niewidomych. Pozawzrokowa percepcja przestrzeni. Gdańsk, Wydawnictwo PG.

Wystawa malarstwa Elżbiety Łysoniewskiej - „Mój świat barw”, opublikowano: https:// pzn.org.pl/wernisaz-elzbiety-lysoniewskiej-w-tyflogalerii [dostęp: 21.08.2019].

Wystawa rzeźby Jana Makowieckiego, opublikowano: https://pzn.org.pl/wystawarzezby-jana-makowieckiego [dostęp: 21.08.2019].

Wystawa Tomasza Kalinowskiego, opublikowano: https://pzn.org.pl/wystawa-tomaszakalinowskiego [dostęp: 21.08.2019].

Zuraw H., 2001, Rewalidacyjne funkcje udziału w kulturze - aplikacje teorii Profesora Aleksandra Hulka. W: G. Dryżałowska (red.), Paradygmaty i przeobrażenia edukacji specjalnej w świetle dorobku Profesora Aleksandra Hulka. Warszawa, Wydawnictwo Akademickie „Żak”, 164-170.

Żuraw H., 2008a, Koncepcja osób niewidomych w poglądach osób z wykształceniem średnim. „Szkoła Specjalna”, 3, 163-174.

Żuraw H., 2008b, Udział osób niepełnosprawnych w życiu społecznym. Warszawa, Wydawnictwo Akademickie „Żak”.

\section{PARTICIPATION OF VISUALLY IMPAIRED PERSONS IN CULTURE}

Abstract: Cultural activity of visually impaired persons plays an essential role in their re-
habilitation. It allows them, among other things, to understand themselves and learn about
their own predispositions, develop creative skills, reduce upsetting emotional tensions related
to their disability and create long-lasting bonds with society. Therefore, it is worth taking 
a closer look at these forms of participation in which visually impaired or partially sighted are involved. Their characteristic was conducted on the basis of a dichotomous division into reception and creativity. Taking into account these two areas, there are indications of strategies aimed at bringing culture closer to people with visual impairment.

Keywords: visually impaired persons, culture participation, reception of culture, expression of culture 